\title{
STRUKTUR, FUNGSI SOSIAL, MAKNA ISTILAH DAN KONSEP SASTRA TATTWA PADA TEKS TUTUR ANGGASTYA PRANA
}

\author{
Putra Adi \\ Universitas Warmadewa \\ iwynputraadisubawa@gmail.com
}

\begin{abstract}
Abstrak
Penelitian ini dilakukan dengan menggunakan dua buah teori yaitu, (1) teori Analisis Wacana dan (2) teori Sosiologi Sastra, termasuk dengan melakukan sejumlah pendekatan seperti (1) pendekatan Filologis yang digunakan untuk mendeskripsikan naskah berupa lontar dan (2) pendekatan budaya, dimana pendekatan ini berfungsi dalam menunjang teori Sosiologi Sastra. Dalam proses pengumpulan data digunakan metode pustaka, yaitu metode pengumpulan data yang lebih banyak dilakukan di perpustakaan. Ketika melakukan analisis data, metode yang digunakan adalah metode hermeneutika atau sederhananya disebut penafsiran.Pada Bab IV dalam tesis ini menyajikan deskripsi naskah dan teks Tutur Anggastya Prana seperti (1) kategori lontar, (2) jumlah lembar, (3) jumlah halaman, dsb. Dengan pendekatan Filologis, naskah dan teks disempurnakan dengan menggabungkan sejumlah data yang serupa dari penyalin yang berbeda, dan juga dilakukan standarisasi teks. Kemudian pada Bab V, struktur teks berupa (1) struktur makro, (2) superstruktur, dan struktur mikro. Pada Bab VI menjelaskan fungsi sosial teks bagi masyarakat Bali seperti (1) profil penyalin naskah, (2) tradisi ritual keagamaan, (3) estetika religius, dan (4) kritik pranata sosial. Selanjutnya pada Bab VII disajikan makna istilah dan konsep-konsep sastra tattwa dari teks sebagai sebuah wacana. Kesimpulan dan saran terdapat pada Bab VIII yang merupakan intisari dari tesis ini. Penulis menyarankan agar para peneliti sastra selanjutnya dapat mengupas makna-makna karya sastra, sastra tradisional Bali khususnya secara lebih luas dan mendalam, agar ilmu pengetahuan masa lampau dapat dinikmati kembali oleh anak dan cucu.
\end{abstract}

Kata kunci: Tutur Anggastya Prana, wacana, sastra, tattwa

\begin{abstract}
This research was completed by using two theories, that are: (1) theory of Discourse Analysis, and (2) theory of Sociology of Literature, including a number of approachs, that are: (1) Philological approach that used to describe lontar manuscript, and (2) cultural approach that used to support the theory of Sociology of Literature. In data collection process, used literature method, that means a method of data collection is mostly done in library. When analyzing the data, used hermeneutics method or usually called interpretation. In Chapter IV of this thesis presented manuscript and text description of Tutur Anggastya Prana, such as: (1) lontar category, (2) number of sheets, (3) number of pages, etc. Using the philological approach, manuscript and text enhanced by combining a number of similar data from different copyist, and also the text was standardizied. Afterwards in Chapter V, structure of the text such as (1) microstructure, (2) superstructure, (3) macrostructure. In Chapter VI describes social functions of the text for Balinese society such as (1) copyist profile, (2) tradition of religous rituals, (3) religious aesthetics, and (4) social critiques. In Chapter VII presented meaning of terms and sastra tattwa concepts from the text as a discourse system.The conclution and suggestions are presented in Chapter VIII which is the essence of this thesis. The author suggests for next researchers can interpreted the meanings of literary works, especially ancient Balinese literature more widely and deeply, in order that knowledge from the past can be enjoyed by our generation.
\end{abstract}

Keywords: Tutur Anggastya Prana, discourse, literary work, tattwa

\section{PENDAHULUAN}

Bahasa Bali termasuk kedalam rumpun bahasa Austronesia. Dibuktikan dengan adanya persamaan-persamaan leksis dianta- ra pendukung bahasa tersebut. Disamping adanya persamaan-persamaan leksis, ditandai juga dengan adanya persamaan bunyi bahasa, baik yang menyangkut bunyi 
konsonan maupun bunyi vokal. Berdasarkan leksis dan beberapa ciri tertentu yang dapat menunjangnya, bahasa Bali dapat diperiodisasikan ke dalam tiga periode yaitu bahasa Bali Kuno, bahasa Bali Tengahan, bahasa Bali Baru.

Sastra Bali merupakan salah satu bentuk pemberdayaan bahasa Bali sebagai wahana ekspresi dari masyarakat Bali, yang telah diwariskan turun temurun sebagai pesona kearifan masa lalu, yang di dalamnya terekam pengalaman estetika, spiritual, sosial, politik dan aspek-aspek lainnya dalam kehidupan masyarakat Bali.

Sastra tulis (sesuratan) juga dikenal dengan nama kesusastran sujana oleh Wayan Budha Gautama (2007: 32). Sastra Bali dalam bentuk tulis merupakan rangkaian dari sastra Bali sebagai teks-teks yang tertuang dalam naskah-naskah tulisan tangan (manuskrip) maupun cetakan, yang sebagian besar disalin dalam lontar.

Lontar adalah sebutan khas Bali untuk sebuah teks yang ditulis tangan pada helaihelai daun lontar (palm-leaf) atau dalam sebutan lain dikenal dengan daun siwalan. Lontar dengan berbagai isi dan jenisnya merupakan salah satu warisan kekayaan sastra orang Bali yang memiliki arti yang sangat penting dan strategis.

Lontar di Bali umumnya bercorak Siwaistik, atau menganut paham Siwa, hal ini begitu erat kaitannya dengan dasar kepercayaan terhadap orang Hindu yang berkembang di Indonesia, Bali khususnya. Adapun jenis-jenis lontar yang bercorak
Siwaistik (dalam Sura, 1993), adalah sebagai berikut: A. Lontar-lontar Tattwa: lontar-lontar jenis ini memuat ajaran filsafat Ketuhanan, di samping itu juga ajaran tentang penciptaan alam semesta, ajaran tentang kelepasan dan sebagainya. B. Lontarlontar Etika: lontar-lontar jenis ini berisi ajaran tentang etika, kebijakan tuntunan untuk menjadi orang sadhu. C. Lontar-lontar Yadnya: lontar ini berisi petunjuk-petunjuk tentang pelaksanaan yadnya, baik mengenai jenis banten atau sesajennya, perlengkapannya dan sebagainya. D. Lontar-lontar Puja: apabila lontar yadnya berisi petunjukpetunjuk pelaksanaan yadnya, maka lontar puja berisi puja untuk menghantarkan yadnya dalam upacara agama.

Lontar Tutur Anggastya Prana masuk ke dalam kategori lontar tattwa yang berarti mengandung tentang filsafat ketuhanan. Lontar ini berkisah tentang seorang yogiswara bernama Ida Bhagawan Anggastya Prana yang telah mencapai pencerahan sempurna. Beliau memiliki dua orang anak, yang laki-laki bernama Sang Surabrata dan yang perempuan bernama Sang Satyakreti. Mereka berdua bertanya banyak hal kepada ayahnya tentang hakikat kelahiran manusia. Begitu pula dengan sang bhagawan yang dengan senang hati mewejangkan pengetahuan tersebut kepada anaknya. Wejangan-wejangan inilah mengandung konsep-konsep yang rumit dan makna yang luas dan mendalam, maka disitulah menariknya teks lontar ini. 
Hal yang sangat utama yang mendasari penelitian ini adalah keinginan untuk mendapatkan makna-makna filosofis dan konsep ajaran luhur dari lontar ini. Dengan menginterpretasi (menafsirkan), maka penulis berharap makna-makna yang terselubung dalam ajaran-ajaran Tutur Anggastya Prana dapat terungkap dan dimengerti oleh masyarakat umum. Karena dengan terselubungnya makna pada sejumlah sastra-sastra Bali, menimbulkan banyak opini miring dalam masyarakat Bali sendiri, seperti anggapan tidak masuk akal, imajiner, mitos, ilmu hitam, dll. Penulis ingin menjelaskan makna ajaran-ajaran tersebut sehingga bisa dipahami dengan baik. Meskipun terdapat pula beberapa hal ajaran yang sulit diterima akal sehat dan tidak logis, hal itu menjadi sebuah batasan tersendiri dalam penelitian ini. Kebijaksanaan jiwa dalam menerima keterbatasan merupakan salah satu jalan untuk menerima isi ajaran secara utuh.

\section{KONSEP DAN LANDASAN TEORI KONSEP}

\section{Konsep}

\section{Konsep Wacana dan Teks}

Sederhananya, pengertian wacana adalah suatu ide atau gagasan yang berusaha disampaikan oleh pembicara atau penulis kepada pendengar atau pembaca dengan bahasa sebagai medianya. Dalam ranah linguistik, wacana digunakan untuk menggambarkan sebuah struktur yang luas melebihi batasan-batasan kalimat (Sunarto, 2001:
119-120). Menurut Abdul Chaer (2014: 267), "wacana adalah satuan bahasa yang lengkap, sehingga dalam hierarki gramatikal merupakan satuan gramatikal tertinggi atau terbesar. Sebagai satuan bahasa yang lengkap, maka dalam wacana juga berarti terdapat konsep, gagasan, pikiran, bahkan ideologi yang utuh dan dapat dipahami pembaca maupun pendengar."

Kemudian mengenai teks, dalam teori bahasa, apa yang dinamakan teks tidak lebih dari himpunan huruf yang membentuk kata dan kalimat yang dirangkai dengan sistem tanda yang disepakatai oleh masyarakat, sehingga sebuah teks saat dibaca dapat mengungkap makna yang dikandungnya. Suatu karya sastra yang berwujud teks dan tertulis dengan bahasa yang khas tidak akan berfungsi apabila tidak ada pembacanya yang menjadi penyambut, penafsir, dan pemberi makna.

\section{KONSEP SASTRA TATTWA}

Istilah sastra tattwa pada judul penelitian ini berpadanan dengan istilah suluk yang berarti jalan ke arah kesempurnaan batin, tasawuf, tarekat, dan mistik. Untuk memunculkan kesan yang lebih ke-Bali-an, maka istilah tattwa dianggap berpadanan dengan istilah suluk itu sendiri. Tattwa berarti ajaran tentang filsafat ketuhanan. Lebih dari itu, tattwa juga berarti tentang filsafat tentang diri sendiri, atas dasar pemahaman Tuhan juga bersemayam dalam diri sendiri, bahkan 
dimana saja. Dan apa saja di alam semesta merupakan bagian Tuhan itu sendiri.

\section{Landasan Teori}

\section{Teori Analisis Wacana}

Teori Analisis Wacana pada penelitian ini menggunakan teori Analisis Wacana Van Dijk. Menurut Van Dijk dalam menganalisis wacana, dapat dilakukan melalui pengabungan tiga analisis yaitu terdiri dari (1) teks, (2) kognisi sosial, dan juga (3) konteks sosial. Ketiga hal tersebut diadopsi dari pendekatan lapangan psikologi sosial, terutama untuk menjelaskan struktur dan proses terbentuknya suatu teks.

Dalam dimensi teks yang dianalisis Van
Dijk membaginya ke dalam tiga tingkatan yang terdiri dari: 1) Struktur makro, adalah makna global atau umum dari suatu teks yang dapat dipahami dengan melihat topik pembicaraan dari suatu teks, 2) Superstruktur, adalah kerangka suatu teks. Maksudnya adalah bagaimana struktur dan elemen wacana itu disusun dalam teks secara utuh, 3) Struktur mikro, adalah suatu makna wacana yang dapat diamati dengan cara menganalisis kata, kalimat, preposisi, anak kalimat, parafrasa, dan sebagainya.

Ketiga struktur tersebut memiliki ranah pengamatan dan elemennya masing-masing, seperti yang digambarkan pada tabel berikut:

Tabel 1: ranah-ranah pengamatan dan elemen-elemen wacana Van Dijk.

\begin{tabular}{|l|l|l|}
\hline Struktur Wacana & Ranah Pengamatan & Elemen \\
\hline \multirow{5}{*}{ Struktur Makro } & $\begin{array}{l}\text { Tematik } \\
\text { (Apa yang dikatakan?) }\end{array}$ & Topik \\
\hline \multirow{5}{*}{ Struktur Mikro } & $\begin{array}{l}\text { Skematik } \\
\text { (Bagaimana pendapat disusun } \\
\text { dan dirangkai?) }\end{array}$ & Skema \\
\hline & $\begin{array}{l}\text { Semantik } \\
\text { (Makna yang ingin ditekankan } \\
\text { dalam teks) }\end{array}$ & $\begin{array}{l}\text { Latar, detail, maksud, praang- } \\
\text { gapanominalisasi }\end{array}$ \\
\cline { 2 - 3 } & $\begin{array}{l}\text { Sintaksis } \\
\text { (Bagaimana pendapat disam- } \\
\text { paikan?) }\end{array}$ & $\begin{array}{l}\text { Aspek gramatikal, kohesi, kata } \\
\text { ganti }\end{array}$ \\
\cline { 2 - 4 } & $\begin{array}{l}\text { Stilistika } \\
\text { (Pilihan kata apa yang dipa- } \\
\text { kai?) }\end{array}$ & Leksikon \\
\cline { 2 - 3 } & $\begin{array}{l}\text { Retoris } \\
\text { (Bagaimana penekanan dil- } \\
\text { akukan?) }\end{array}$ & Grafis, majas, ekspresi \\
\hline
\end{tabular}

\section{Struktur Makro}

\section{a. Tematik}

Tematik atau tema adalah suatu amanat utama yang disampaikan oleh penulis melalui tulisannya (Keraf, 1980: 107).
Jenis tema berdasarkan pokok pembicaraanya menurut Shipley (dalam Sayuti, 2000:197) terdiri dari lima tipe, yaitu: 1) Tema jasmaniah (physical), merupakan tema berbicara tentang keadaan manusia 
secara jasmani, 2) Tema organik (moral), merupakan tema yang mencakup hal-hal yang berhubungan dengan moral manusia, 3) Tema sosial, merupakan tema yang mencakup masalah sosial. Hal-hal yang di luar masalah pribadi, dalam pengertian ini manusia sebagai makhluk sosial, 4) Tema egoik, merupakan tema yang menyangkut reaksi-reaksi pribadi manusia sebagai individu yang senantiasa menuntut pengakuan hak-hak individual, 5) Tema ketuhanan (divinity), merupakan tema yang berkaitan dengan kondisi dan situasi manusia sebagai makhluk ciptaan Tuhan.

Apabila berdasarkan cakupannya, tema dibagi lagi menjadi dua hal, yaitu, 1) Tema pokok/tema mayor, merupakan makna pokok cerita yang menjadi gagasan umum karya sastra, tidak hanya terdapat dalam bagian tertentu saja, 2) Tema tambahan/ tema minor, merupakan tema tambahan yang hanya terdapat pada bagian-bagian tertentu saja.

\section{Superstruktur}

\section{a. Skematik}

Skema merupakan alur penyajian suatu teks. Maksudnya adalah bagaimana struktur dan elemen wacana itu disusun dalam teks secara utuh yang merupakan alur dari sebuah teks yang terdiri dari pembukaan, isi dan penutup.

Juga ada beberapa elemen skema lainnya yang disebutkan menurut Van Dijk: 1) Skema person (Person Schemas): skema ini adalah bagaimana cara seseorang dalam menggambarkan dan memandang orang lain, 2) Skema diri (Self Schemas): skema ini membicarakan bagaimana diri sendiri dipahami, dan digambarkan oleh seseorang, 3) Skema peran (Role Schemas): pada skema ini berhubungan dengan bagaimana seseorang memandang dan menggambarkan peranan dan posisi yang ditempati seseorang dalam masyarakat, 4) Skema peristiwa (Event Schemas): skema ini merupakan skema yang berhubungan tentang seseorang memadang peristiwa.

\section{Struktur Mikro}

\section{a. Semantik}

Pada pengertian umum, semantik adalah disiplin ilmu bahasa yang menelaah makna satuan lingual, baik makna leksikal maupun makna gramatikal.

\section{b. Sintaksis}

Segi sintaksis berhubungan dengan penataan bentuk dan susunan kalimat membangun penggungkapan gagasan, ide yang logis. Bagian kalimat atau kalimat yang satu dijalin dengan bagian atau kalimat yang lain sehingga membentuk kesatuan yang padu.

\section{c. Stilistika}

Stilistika adalah gaya (style), yaitu suatu cara yang digunakan penulis atau pembicara untuk menyatakan maksudnya dengan menggunakan gaya bahasa. Gaya bahasa mencakup diksi atau pilihan kata untuk membentuk citra makna tertentu. Melalui 
pemilihan kata, peristiwa yang sama dapat digambarkan dengan kata yang berbeda.

\section{d. Retoris}

Retoris merupakan gaya interaksi pembicara atau penulis ketika seseorang berbicara atau menulis. Misalnya dengan pemakaian kata-kata yang berlebihan (hiperbolik), atau bertele-tele. Retoris juga mempunyai fungsi bersifat persuasif dan berhubungan erat dengan bagaimana pesan itu ingin disampaikan kepada khalayak.

\section{Teori Sosiologi Sastra}

Fokus perhatian sosiologi sastra adalah pada isi karya sastra, tujuan, serta hal-hal lain yang tersirat dalam karya sastra itu sendiri dan yang berkaitan dengan masalah sosial. Menurut pendapat Wellek dan Warren, sosiologi sastra memasalahkan karya sastra itu sendiri, mengkaji apa yang tersirat dalam karya sastra dan apa yang menjadi tujuannya dan mengkaji pembaca serta pengaruh sosial karya sastra. Sosiologi karya sastra adalah kajian yang mengkaji karya

sastra dalam hubungannya dengan masalahmasalah sosial yang ada dalam masyarakat sebagai bentuk fungsi sosialnya.

Wellek dan Warren (1956:84, 1990:111) telah membagi sosiologi sastra sebagai berikut: 1) Sosiologi pengarang: profesi pengarang, dan institusi sastra. Masalah yang berkaitan di sini adalah latar belakang sosial status pengarang, dan ideologi pengarang yang terlibat dari berbagai kegiatan pengarang di luar karya sastra, karena setiap pengarang adalah warga masyarakat, ia dapat dipelajari sebagai makhluk sosial, 2) Sosiologi karya sastra: yang memasalahkan karya sastra itu sendiri yang menjadi pokok penelaahannya atau apa yang tersirat dalam karya sastra dan apa hal yang menjadi tujuannya, 3) Sosiologi sastra yang memasalahkan pembaca dan dampak sosial karya sastra, pengarang dipengaruhi dan mempengaruhi masyarakat.

\section{PEMBAHASAN}

\section{Deskripsi Naskah}

Tabel 2: Deskripsi naskah secara terperinci

\begin{tabular}{|l|l|}
\hline Judul & Tutur Anggastya Prana \\
\hline Ukuran & P: $44 \mathrm{~cm}, \mathbf{L}: 3,5 \mathrm{~cm}$ \\
\hline Jenis Media & Lontar/Rontal/Ental/Siwalan \\
\hline Kategori & Tutur \\
\hline Jumlah Lembar & 26 lembar \\
\hline Jumlah Halaman & 24 halaman \\
\hline Pengarang/penyusun & Tidak diketahui \\
\hline Penyalin & I Wayan Raos (alm) \\
\hline Lokasi Naskah Ditemukan & Banjar Kedisan Kelod, Desa Kedisan, Kecamatan Tegalalang, Gianyar, Bali \\
\hline Bahasa Naskah & Bahasa Bali \\
\hline Huruf Naskah & Aksara Bali \\
\hline Kalimat-Kalimat Awal & $\begin{array}{l}\text { Om Awighnam Astu Nama Siddham. Iki tutur Bhagawan Anggastya Prana, ngaran, Ida } \\
\text { Bhagawan Anggastya Prana, madruwē putra kalih diri, lanang asiki, istri asiki, sane lanang } \\
\text { duwuran, mawasta Sang Sura Bratha, sanē alitan istri, mapesengan Sang Satya Kreti }\end{array}$ \\
\hline Kalimat-Kalimat Akhir & $\begin{array}{l}\text { Yan wong wadon, angucapin nyamane, mantra, Ong Nini Sang Séda Rasa, Sang Sēda Sakti, } \\
\text { Sang Ratu Mas Kuwindha, Sang Ratu Aji Putra Putih, jalan madius, poma, poma, poma. }\end{array}$ \\
\hline
\end{tabular}




\section{Suntingan teks pembuka (halaman 0)}

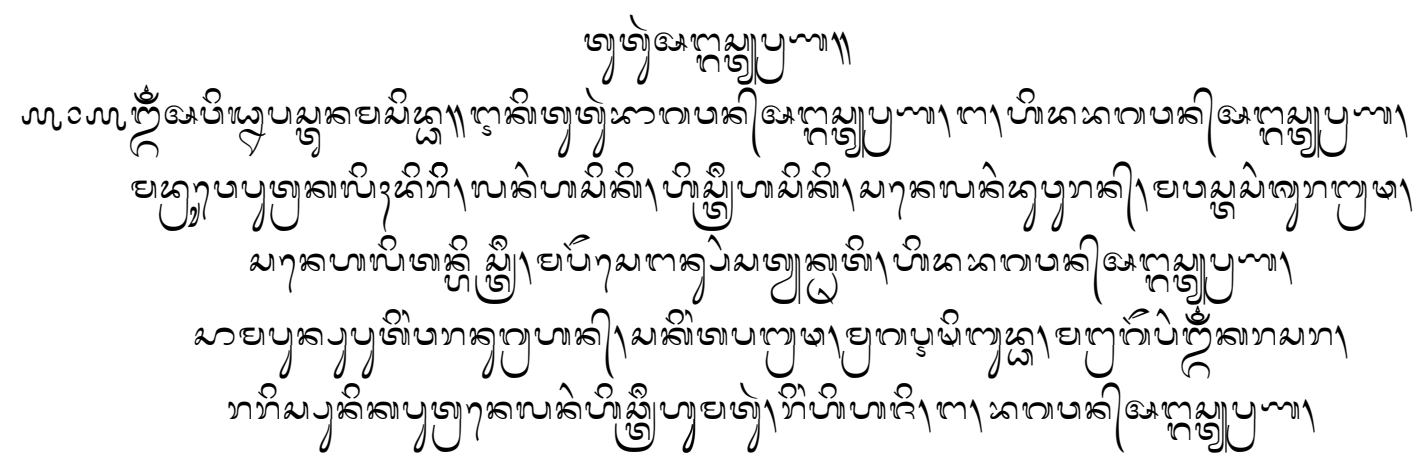

Tutur Anggastya Prana

Om Awighnam Astu Nama Siddham. Iki tutur Bhagawan Anggastya Prana, ngaran Ida Bhagawan Anggastya Prana, madruwē putra kalih diri, lanang asiki, istri asiki, sanē lanang duwuran mawasta Sang Sura Bratha, sanē alitan istri, mapesēngan Sang Satya Kreti, Ida Bhagawan Anggastya Prana sampun puputing waranugrahan saking tapa bratha, meraga rsi Buddha, mangregepang Ong Kara Aksara, raris punika putrane lanang istri umatur, ring $i$ aji, ngaran Bhagawan Anggastya Prana

\section{Tutur Anggastya Prana}

Ya Tuhan semoga tiada halangan. Ini merupakan nasihat dari Bhagawan Anggastya Prana. Beliau memiliki dua orang anak, satu laki-laki, satu lagi perempuan. Si sulung laki-laki, bernama Sang Sura Bratha, si bungsu perempuan bernama Sang Satya Kreti. Ida Bhagawan Anggastya Prana telah ber-

hasil memperoleh anugerah dēwata, buah dari tapa brata beliau, bergelar rsi Buddha/ Bodha, menghayati aksara Ongkara (ý). Kemudian anaknya dengan hormat berkata kepada sang ayahanda, Bhagawan Anggastya Prana;

\section{Suntingan teks bagian isi/pertengahan (halaman 6)}

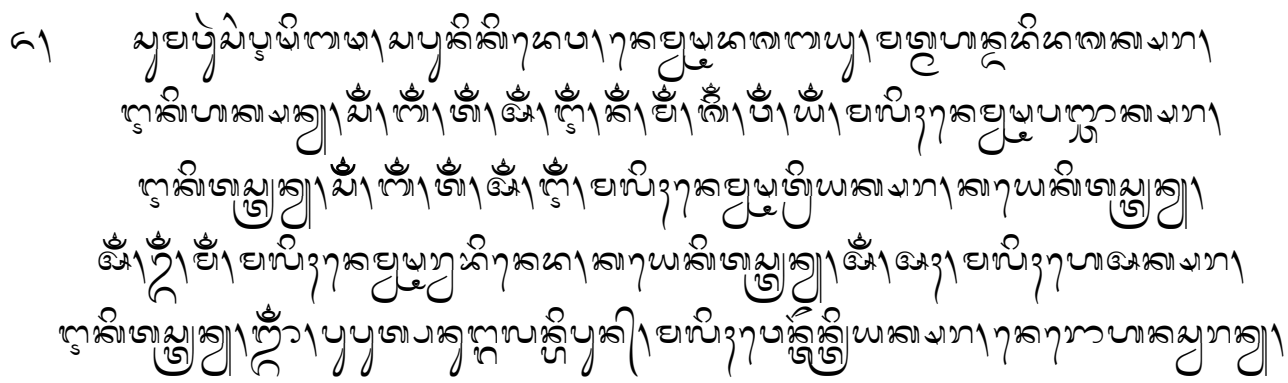

sumawur Sang Rsi Bratha, sapuniki dēwa, nē mawasta Dasa Bayu, matemahan dadi Dasa Aksara, iki aksaranya, Sang, Bang,Tang, Ang, Ing, Nang, Mang, Sing, Wang, Yang, malih nē mawasta Panca Aksara, iki tastranya, Sang, Bang, Tang, Ang, Ing, malih nē mawasta Triyaksara, kayēki tastranya, Ang, Ung, Mang, malih nē mawasta Rwa Bhinèda, kayēki tastranya Ang, Ah, malih Ëka Aksara,

iki tastranya, Ong, puput panunggalan ipun, malih wēnten Triyaksara Amsa, puniki hana suaranya,'ng'

Sang Rsi Bratha menjawab, "Begini anakku, yang disebut Dasa Bayu (sepuluh energi), dilambangkan dengan Dasa A ksara (sepuluh aksara suci) yaitu, Sang $\left(\mathrm{s}^{\mathrm{o}}\right)$, Bang $(\mathrm{b}$,$) , Tang \left(\mathrm{t}^{\mathrm{o}}\right)$, Ang $(\ddot{0})$, Ing $(\div)$, Nang $\left(\mathrm{n}^{\mathrm{o}}\right)$, Mang $(1 / 2)$, Sing $\left({ }^{\prime} \mu\right)$, Wang $\left(\mathrm{w}^{\mathrm{o}}\right)$, Yang $\left(\mathrm{y}^{\mathrm{o}}\right)$. Yang disebut Panca A ksara (lima aksara suci) yaitu, Sang $\left(\mathrm{s}^{\mathrm{o}}\right)$, Bang $(\mathrm{b}$,$) , Tang \left(\mathrm{t}^{\mathrm{o}}\right)$, Ang $(\ddot{\mathrm{o}})$, Ing $(\div$ ). Juga ada yang disebut Triyaksara/Tri Aksara (tiga aksara suci) yaitu, Ang (ö), Ung (̂ิ), Mang (1/2). Kemudian ada yang disebut aksara Rwa Bhinēda/Dwi A ksara (dua aksara suci) yaitu, Ang (ö) dan Ah (Á ;). Yang terakhir disebut $\bar{E} k a$ Aksara (aksara suci tunggal) yaitu, Ong (b), selesailah penyatuan semuanya. Ada lagi yang disebut Tri Aksara A msalA ksara A msa berbunyi "ng", 


\section{Suntingan teks bagian akhir (halaman 24)}

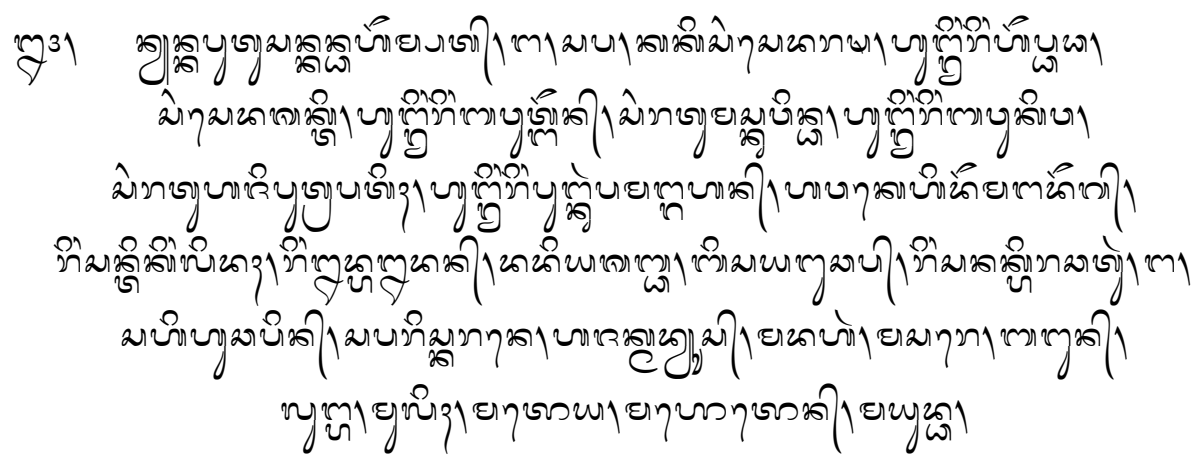

Nian kaputusan kanda empat ngaran, sapa, Kaki Sang Sēda Rasa, ungguing ring hep dada, Sang Sèda Sakti, ungguing ring bahu tengen, Sang Ratu Mas Kuwindha, ungguing ring bawu kiwa, Sang Ratu Aji Putra Putih, ungguing ring pungkur pamanggahan awake ida mangadeg, ring cantiking lidah, ring paled-ledan, dadi ya sabda, bisa ya ngucap, ring sanak ira catur, ngaran, sai ucapin, sapari sekaranē, ajak madius, madaar, mesarē, bangun, lunga, mulih, matoya, maoton, mayudha,

"Berikut ini adalah cara dalam memanggil keempat saudara, inisiasikan dahulu, Kaki Sang Sēda Rasa letakan (visualkan) di depan dada, Sang Sēda Sakti di bahu kanan, Sang Ratu Mas Kuwindha di bahu kiri, Sang Ratu Aji Putra Putih di punggung, di tubuhmu mereka semua berada, pada anak lidah/anak tekak, pada tenggorokan menjadi suara yang mampu berbicara, selalu ingatlah kepada saudara-saudaramu itu, selalu ucapkan dan ajak di setiap aktivitas yang kalian kerjakan, ajak mandi, makan, tidur, bangun, bepergian, pulang, ruwatan, otonan, berperang,

\section{Struktur Makro}

Ranah pengamatan dari struktur makro adalah tematik atau tema. Teks Tutur Anggastya Prana terindikasi bahwa pokok pembicaraan mengandung dua tema yaitu (1) tema ketuhanan (divinity) dan (2) tema jasmaniah (physical). Terlihat pada kutipan teks berikut:

\section{Transliterasi}

.....sumawur Bhagawan Anggastya Prana, uduh anak ingsun kalih, apa pamilakun $i$ dèwa ring bapa, agēwarahan nanak, lamakan weruh sira bapa, matur sang kalih pukulun Sang Maha Yakti, enak pada asung lugraha, ring kawula pakulun, hana sedeng tinanya ranak sang rsi, satingkahē dados jadma, sampunapi kawitè dumun, sang apa ana$w \bar{e}, \ldots . .($ halaman 1)

\section{Terjemahan}

.....Bhagawan Anggastya Prana menjawab; "Anakku sekalian, apa kiranya yang ingin kalian ketahui dari ayahanda? silahkanlah!" "Hormat hamba kepada Sang Maha Yakti (sebutan lain sang rsi), semoga kami diberkati, hamba ingin bertanya kepada ayahanda tentang kesejatian manusia, bagaimana awal mulanya, dan bagaimana semestinya?'..... (halaman 1)

Dalam teks di atas terdapat kalimat pertanyaan seperti berikut "Hamba ingin bertanya kepada ayahanda tentang kesejatian manusia, bagaimana awal mulanya, dan bagaimana semestinya?", yang berarti pokok pembicaraannya mengarah pada manusia sebagai makhluk jasmani dan makhluk Tuhan, atau sesuatu yang bersifat keilahian. Semakin jauh diamati, pada bagianbagian akhir dari teks, topik yang dibicarakan mengarah pada urusan ritus keagamaan. Itu berarti terdapat juga unsur sosial di dalamnya. Alasan ini diperkuat dari kutipan teks berikut: 


\section{Transliterasi}

.....inggih ratu sang rsi, yan sampun kepus nabin ipun, wēnten prayanan ipun malih, sumawur sang rsi, wēnten dēwa patut palikraman ipun, tunasang pabersihan ring dēwa kemulan, bantennya daksina asoroh, nasi warna sapuputnē, tur menampiang sang rarē, tunasang toya, nasi mawarna di jalanē manakan, asoroh, tur ngutang reged sang bajang colongēe, malih sig luwunē matanem, banten nasi warna, punika balinia, tunasang ring dēwa, idihang ring wusadha yēh bersihan, sami bersihin, yēh bajangan, ring genahe manakan, mèmè bapanya anakè cerik, bajang colongē sig luwunē metanem, sami lukat, matepung tawar, mabersih, malukat,.....(halaman 21)

\section{Terjemahan}

.....lalu bagaimana jika bayi telah lepas tali pusarnya, adakah tata caranya?" Menjawab sang rsi, "Ada anakku, yang demikian mohonkan pembersihan di Dēwa Kemulan, dengan sesajen (banten) yaitu sebuah daksina, dan nasi warna (nasi tumpeng putih dan kuning), serah terimakan kepada bayi secara simbolik, kemudian percikan air suci (tirtha), juga nasi warna (segehan panca warna, putih, kuning, merah, hitam, dan kombinasi semuanya/brunbun) yang nantinya akan dihaturkan di depan pintu rumah setelah ari-ari dan luwu/lamas ditanam, sebelum semua dilakukan, mohonkan dahulu pada dewa untuk merestui air pembersihan, kemudian bersihkan (percikan) semuanya, yēh bajangan (air bekas mencuci ari-ari dan luwu/lamas), pada tempat melahirkan, ibu dan bapak sang bayi, bajang colong (salah satu nama kekuatan dari 108 yang menjaga bayi selama kandungan) pada tempat menanam ari-ari dan luwu/lamas, lukat (ruwat) semuanya, matepung tawar, dan dibersihkan.....(halaman 21)

Berdasarkan dua di atas sudah dapat ditentukan bahwa pada teks Tutur Anggastya Prana mengandung tiga tema sekaligus,

(1) tema ketuhanan (divinity) dan (2) tema jasmaniah (physical), dan (3) tema sosial. Namun yang paling ditekankan disini adalah unsur keilahian yang mendominasi setiap tuturan, itu artinya tema pokok/tema mayor dari karya sastra ini adalah tema ketuhanan (divinity).

\section{Superstruktur।}

Pada superstruktur menjabarkan kerangka dari teks Tutur Anggastya Prana. Berikut adalah skema dari teks Tutur Anggastya Prana:

\section{a. Pembukaan}

Paragraf pembuka mencoba mengarahkan pikiran si pembaca pada gambaran awal terhadap isi teks. Paragraf pembukaan di atas terdiri dari:

1) Sebuah teks doa si penulis kepada Tuhan: "Om Awighnam Astu Nama Siddham." yang berarti "Ya Tuhan semoga tiada halangan."

2) Sebuah teks yang memberikan gambaran umum tentang teks Tutur Anggastya Prana: "Iki tutur Bhagawan Anggastya Prana" berarti "Ini merupakan wejangan Bhagawan Anggastya Prana."

3) Sebuah teks pengenalan tokoh: ".....Ida madruwē putra kalih diri, lanang asiki, istri asiki, sanē lanang duwuran, mawasta Sang Sura Bratha, sanē alitan istri, mapesēngan Sang Satya Kreti....." yang berarti "Beliau memiliki dua orang anak, satu laki-laki, satu lagi perempuan, si sulung laki-laki bernama Sang Sura Bratha, si bungsu perempuan bernama 


\section{Sang Satya Kreti."}

4) Sebuah teks penggambaran kesan terhadap tokoh utama: “....Ida Bhagawan Anggastya Prana, sanē sampun puputing waranugrahan, saking tapa bratha, meraga rsi Buddha, malih mangregepang Ong Kara Aksara....." yang berarti "Ida Bhagawan Anggastya Prana telah berhasil memperoleh anugerah dēwata, buah dari tapa brata beliau, bergelar rsi Buddha/Bodha, penghayatan pada aksara Ong Kara."

5) Sejumlah teks tanya jawab yang memulai pembicaraan: (1) “.....singgih ratu paduka sang rsi, tabē pakulun kaula matur, mangde tan katibēn tulah sarik, raja panulah saking Hyang Suksma....." yang berarti "oh sang rsi mulia, maafkan ananda sebelum bertutur, agar terhindar dari kualat dan kutuk dari leluhur dan Hyang Suksma.” (2) “.....uduh anak ingsun kalih, apa pamilakun i dēwa ring bapa, napi agēwarahan nanak, lamakan weruh sira bapa...." yang berarti "Anakku sekalian, apa yang ingin kalian ketahui dari ayahanda? silahkanlah!” (3) “.....pukulun Sang Maha Yakti, mangda ènak pada asung lugraha, ring kawula pakulun, hana sedeng tinanya ranak sang rsi, satingkahē dados jadma, tur sampunapi kawitè dumun, sang apa ana$w \bar{e}$....." berarti "harap hamba semoga mendapat berkat, hamba ingin bertanya kepada ayahanda tentang kesejatian manusia, bagaimana awal mulanya, dan bagaimana semestinya?"

\section{b. Isi}

Isi sama dengan topik yang dibicarakan. Berikut merupakan sejumlah paragraf yang mewakili isi atau topik pembicaraan dalam teks Tutur Anggastya Prana:

1) Topik tentang terciptanya manusia secara simbolik:

\section{Transliterasi}

.....i dēwa meraga Siwatma, duk sang bapa, muang sang ibu, kari jajaka, $i$ dèwa ngalih tongos, sang bapa sang ibu, pada ngelah manah, pada kasmaran, semara sang bapa, maaran Semara Jaya, semara sang ibu maaran Semara Ratih, i dēwa maaran Semara Sunia..... (halaman 1)

\section{Terjemahan}

.....Kalian merupakan perwujudan Siwatma (kemuliaan sejati), tatkala ayah dan ibu masih jejaka dan gadis, jiwa kalian pada alam kesunyian mulai mencari tempat. Ayah dan ibu terpaut perasaan satu sama lain, saling kasmaran. Benih asmara muncul dari ayah yang disebut Semara Jaya, benih asmara dari ibu disebut Semara Ratih, dan kalian disebut Semara Sunia....(halaman 1)

2) Topik kedua, dimana teks Tutur Anggastya Prana berbicara tentang Kanda Pat, yaitu empat saudara gaib manusia:

\section{Transliterasi}

.....atmane nyusup ring manusa, tatiga ngawakin manusanē kari urip, suba ada dèwa kala atma ngawakin, ada nyamania patpat nyarengin, ari-ari, yēh nyom, metu saking bapa, getih, luwu, metu saking $i$ mèmē, punika ari-arinē, yēh nyomē, getihè, luwune, sami kadadin tanah, sarin pangan kinumnē dadi kama, kaman $i$ mèmēnē, kaman $i$ bapanē, kamanè dadi manusa, 
bayun kamanē dadi kala, rasan kamanē, dadi atma, sarin kamanē, dadi dēwa, krana hana Kanda Empat Bhuta, Kanda Empat Atma, Kanda Empat Dēwa, bayun nyamanē dadi kala, rasan kamanē dadi atma, sarin kama dadi dēwa, ika ngempu manusanē, duking kari maurip, tekaning pati, ika ngawē ala muang ayu, ngawē pati, ngawēe urip, ngawē papa, ngawē suargan idup, suargan mati, ngawē buung, ngawē payu.... (halaman 4-5)

\section{Terjemahan}

.....atma menyusupi manusia, membawa dua unsur lainnya menyebar dalam diri manusia dan menyebabkan manusia hidup. Selain unsur dēwa, kala, dan atma, ada juga empat hal yang turut menyertai, yaitu, ari-ari (tembuni/plasenta), yēh nyom (air ketuban), yang berasal dari ayah, getih (darah), luwu/ lamas (selaput/amnion), yang berasal dari ibu. Demikianlah ari-ari, yēh nyom, getih, luwu/lamas, nantinya akan sama-sama menjadi tanah, sari-sari makanan dan minuman menjadi kama ibu dan kama ayah, dan kamalah merupakan cikal bakal manusia. Bayu (energi) dari kama menjadi kala, rasa dari kama menjadi atma, sari dari kama menjadi dēwa, maka dari situlah muncul Kanda Empat Bhuta, Kanda Empat Atma, dan Kanda Empat Dēwa. Merekalah yang mengasuh dan melindungi manusia selama masih hidup hingga mati, mereka juga yang menyebabkan baik juga buruk, penyebab mati, penyebab hidup, penyebab dosa, penyebab surga dan neraka ketika masih hidup maupun setelah mati, penyebab gagal dan berhasil suatu tindakan....(halaman 4-5)

3) Pada topik ketiga, isi teks berbicara tentang Dasa Aksara, yaitu sepuluh aksara suci pada diri manusia:

\section{Transliterasi}

.....uduh anak mas ingsun, asapuniki parikandan ipun, Dasa Bayu dadi Dasendriya, ika panunggalan, Panca Bayu dadi Pancēngdriya, ika panunggalannya, dadi tatiga, bayu, sabda, idep, malih tunggal dadi kekalih, nē kekalih tunggal, dadi asiki, yan sapunika sapunapi kandan ipun malih, kēnē dèwa, ilang letuhe, suarga juga ka- panggih.....(halaman 5-6)

\section{Terjemahan}

.....Anakku sekalian, beginilah sesungguhnya, Dasa Bayu (sepuluh energi) menjadi Dasendriya/Dasa Indria (sepuluh indra) itu penyatuannya. Panca Bayu (lima energi) menjadi Pancēngdriya/ Panca Indria (lima indra), itu penyatuannya, kemudian terbagi menjadi tiga (Tri Pramana); bayu, sabda, idep, kemudian menjadi dua bagian, dari dua menjadi tunggal, menyebabkan lenyap kotoran batin sehingga dapat merasakan surga....(halaman 5-6)

4) Pada topik keempat, teks Tutur Anggastya Prana menjelaskan tentang tradisi ritual:

\section{Transliterasi}

.....ne madan pradana idup, matelah telah, mangroras lemengin, kepus pungsed, macolongan, matelu bulan, maoton, magubah, mabyakawonan, makalah kalahan, makala ening, madudus mawinten agung, matatah, punika ngawē bersih, sekala idupē. Malih pradana mati, nutugang maka telun, matelah telah solas dina, ngabēn, matuun, nyekah, mamukur, punika gawēne, sama telah telah kepus pungsed samanya, yan tan sang Rsi nora weruh, mawak Sang Hyang Atma, berana telah Sang Hyang Atma kasasar, yan sang rsi, weruha ngarad atma nira, mulah weruh ngarad Sang Hyang Atma, tur molih panugrahan, saking tapa bratha, weruh ngarad nyaman sang mati, molih suarga.....(halaman 7$)$

\section{Terjemahan}

.....Ruwatan saat hidup begini tahapannya: matelah-telah, mangroras lemengin, kepus pungsed, macolongan, matelu bulan, maoton, magubah, mabyakawon, makalahkalah, makala ening, madudus mawinten agung, matatah (potong gigi), semua itu dapat membantu membersihkan diri selama hidup. Peruwatan saat mati, begini tahapannya: nutugang maka telun, matelahtelah solas dina, ngabèn, matuun, nyekah, mamukur. Sebaiknya peruwatan tersebut dilakukan. Namun, jika rsi/pendeta yang melakukan peruwatan ini tidak paham dan 
terampil, akan menyebabkan harta benda habis dan atma menjadi tersesat. Sebaliknya, jika rsi/pendeta yang meruwat melakukan dengan baik, beliau akan mampu menuntun atma ke jalur semestinya, bahkan bersamaan dengan keempat saudara (Kanda Empat) dari orang yang meninggal tersebut, sehingga memperoleh tempat semestinya tergantung karma mereka.... (halaman 7)

\section{c. Penutup}

Penulis tidak menemukan paragraf maupun kalimat yang mencerminkan akhir dari teks ini. Hal tersebut disebabkan teks Tutur Anggastya Prana yang menjadi data induk penulis, bukanlah data yang utuh.

\section{Struktur Mikro}

\section{a. Sintaksis}

Sintaksis adalah tatabahasa yang membahas hubungan antara kata dalam tuturan.

\section{1) Kohesi Gramatikal}

Pengertian kohesi gramatikal adalah kohesi yang terbentuk oleh tata bahasa yang terdiri dari referensi, substitusi, dan konjungsi.

\section{a) Referensi}

adalah salah satu jenis kohesi gramatikal dalam wacana, dalam hal ini adalah wacana sastra berupa satuan lingual tertentu yang mengacu pada satuan lingual lain (suatu referen) yang mendahului atau mengikutinya. Referensi yang terdapat pada teks $T u$ tur Anggastya Prana diantaranya adalah referensi persona. Referensi persona atau pronomina persona, atau yang lebih umum disebut juga kata ganti orang, dapat dilihat pada kutipan berikut:

\section{Transliterasi}

.....ida madruwē putra kalih diri, lanang asiki, istri asiki, sanē lanang duwuran, mawasta Sang Sura Bratha, sanē alitan istri, mapesēngan Sang Satya Kreti.... (halaman 0)

\section{Terjemahan}

.....beliau memiliki dua orang anak, satu laki-laki, satu lagi perempuan. Si sulung laki-laki, bernama Sang Sura Bratha, si bungsu perempuan bernama Sang Satya Kreti.....(halaman 0)

\section{b) Subtitusi}

adalah proses atau hasil penggantian unsur bahasa oleh unsur lain dalam satuan yang lebih besar untuk memperoleh unsurunsur pembeda selain itu juga untuk menjelaskan suatu struktur tertentu (Kridalaksana, 2008). Berikut adalah contoh substitusi dalam teks Tutur Anggastya Prana:

\section{Transliterasi}

.....ane madan papa mati, anē mati salah pati, sapunika dadi kunda tektek lalintah, iris-iris poh,.....(halaman 11)

\section{Terjemahan}

.....papa mati adalah orang yang mengambil jalan mati yang tidak pantas, jalan seperti itu, kelak terlahir sebagai lintah, irisiris poh (sejenis binatang melata).... (halaman 11)

Pada kutipan di atas terdapat kata sapunika (Ami; alus mider), dalam Kamus Bali-Indonesia memiliki arti leksikal "demikian itu". Dalam terjemahan teks di 
atas, frasa "demikian itu" berpadanan dengan makna "jalan seperti itu", karena penerjemahaan disesuaikan dengan konteks pembicaraan.

\section{c) Konjungsi}

dipergunakan untuk menggabungkan kata dengan kata, frase dengan frase, klausa dengan klausa, kalimat dengan kalimat, serta paragraf dengan paragraf (Kridalaksana, 1984: 105). Berikut adalah contoh konjungsi dalam teks Tutur Anggastya Prana:

\section{Transliterasi}

1) ....Aksara Rwa Bhinēda, ika dadi margan pati, muang margan urip..... (halaman 2)

\section{Terjemahan}

.....Aksara Rwa Bhinēda (dualitas kehidupan) dalam mikrokosmos /tubuh, berfungsi sebagai jalur hidup dan mati.....(halaman 2)

\section{Transliterasi}

2) .....kèto samanya, yadin sang brahmana muang rsi, utawi bhujangga rsi, yan tan weruh.....(halaman 8)

\section{Terjemahan}

.....Begitu juga halnya, jika sang brahmana, rsi, atau bhujangga rsi tak paham akan hal tersebut.....(halaman 8)

\section{b. Stilistika}

Pengertian stilistika adalah gaya (style), yaitu suatu cara yang digunakan penulis atau pembicara untuk menyatakan maksudnya dengan menggunakan gaya bahasa. Salah satu bentuk stilistika adalah diksi. Diksi adalah pemilihan kata-kata yang sesuai dengan apa yang hendak kita ungkapkan. Pemilihan kata-kata tentunya melalui berbagai pertimbangan untuk mendapatkan efek yang dikehendaki. Efek yang dimaksud adalah kesan atau citra mental yang ditimbulkan kepada pembaca akibat adanya interaksi psikologis oleh katakata. Efek, kesan atau citra mental tersebut dapat dilihat pada kutipan berikut:

\section{Transliterasi}

....Ida Bhagawan Anggastya Prana, sampun puputing waranugrahan, saking tapa bratha, meraga rsi Buddha, mangregepang Ongkara Aksara,....(halaman 0)

\section{Terjemahan}

.... Ida Bhagawan Anggastya Prana telah berhasil memperoleh anugerah dēwata, buah dari tapa brata beliau, bergelar rsi Buddha/Bodha, menghayati aksara Ongkara (宅).....(halaman 0$)$

Kutipan teks di atas, pengarang ingin membentuk kesan tertentu terhadap pembaca, Ida Bhagawan Anggastya Prana, si tokoh utama, merupakan orang yang suci dan sakti. Diksi yang dipakai tampak pada klausa "sampun puputing waranugrahan", yang memiliki arti "berhasil memperoleh anugerah dēwata".

\section{c. Retoris}

Retoris merupakan gaya interaksi pembicara/penulis ketika seseorang berbicara atau menulis. Salah satu bentuk dari retoris adalah majas. Majas adalah kiasan. Berikut adalah sebuah bentuk dari majas perbandingan deprsonifikasi: 


\section{Transliterasi}

.....malih matur sang kalih, inggih ratu sang rsi, yan jadmanē kaliha rabi, wēnten palikraman ipun, sumawur sang rsi, inggih wènten dèwa, yan tan wènten sapa, boya minakadi patemon kidang menjangan, saluir sato manusa.....(halaman 20)

\section{Terjemahan}

.....anak sang $r$ si bertanya kembali, "Baiklah sang $r s i$, ananda telah memahaminya, kemudian bagaimana tentang pernikahan, adakah normanya?" Sang rsi menjawab, "Tentu saja ada anakku, jika tidak, apa bedanya manusia dengan perilaku binatang, bagaikan sepasang rusa yang tak mengenal kepatutan dan etika.....(halaman 20)

Depersonifikasi merupakan majas yang menampilkan manusia sebagai binatang, benda-benda alam, atau benda lainnya. Kutipan teks di atas menunjukan bagaimana manusia melakukan pernikahan/ perkawinan yang tanpa mengikuti norma-norma yang disepakati, diumpamakan bagaikan sepasang rusa yang baginya tidak mengenal aturan-aturan tentang kemanusiaan. Unsur yang dibandingkan adalah sikap manusia dengan binatang rusa.

\section{Sosiologi Sastra}

\section{a) Tradisi Ritual Keagamaan}

Teks Tutur Anggastya Prana cukup banyak berbicara perihal ritual (upacara) dan sesajen (upakara) yang tergolong manusa yadnya, yaitu korban suci bagi diri sendiri (pemberdayaan diri) dan terhadap sesama manusia. Diri yang dimaksud bukan hanya yang bersifat jasmani, melainkan unsurunsur rohani dan juga keilahian termasuk juga di dalamnya. Berikut adalah sejumlah ritus keagamaan yang ditemukan dalam teks Tutur Anggastya Prana:

1) Ritual pengrujakan: ritual saat istri mengidam.

2) Ritual panglukatan bobotan: meruwat kehamilan.

3) Ritual magedong-gedongan: peruwatan kehamilan usia tua.

4) Ritual pamapag rarē: adalah ritual menyambut bayi yang baru lahir.

5) Ritual mendem ari-ari: ritual menanam plasenta.

6) Ritual ngerorasin: duabelas hari bayi.

7) Ritual kepus puser: lepasnya tali pusar bayi.

8) Ritual namakarana: adalah pengukuhan nama bayi.

9) Ritual abulan pitung dina: 42 hari bayi.

10)Ritual matelu bulanan: tiga bulanan bayi (105 hari).

11)Ritual otonan: merupakan ritual peringatan kelahiran.

\section{Semantik}

Pada pengertian umum, semantik adalah disiplin ilmu bahasa yang menelaah makna satuan lingual, baik makna leksikal maupun makna gramatikal.

\section{a. Makna Istilah Dalam Konsep}

\section{Kedewataan}

\section{1) Sang Hyang Tiga Wisēsa}

Sang Hyang Tiga Wisēsa berarti tiga pribadi sakti nan mulia. Kata Wisēsa berarti sakti, padanan istilah yang lebih umum digunakan adalah Tri Sakti. Tiga pribadi sakti nan mulia tersebut ialah Sang Hyang 
Brahma, Sang Hyang Wisnu, dan Sang Hyang Siwa.

\section{2) Nawa Sanga}

Nawa Sanga atau lengkapnya Déwata Nawa Sanga juga disebut Nawa Dēwata adalah sembilan (nawa) entitas dewata penguasa sembilan wilayah. Delapan diantaranya berada pada masing-masing penjuru mata angin, dan satu pada poros tengah di alam semesta.

\section{3) Panca Rsi dan Sapta Rsi}

$R s i$ atau Rishi adalah seorang suci yang mendapat wahyu dalam agama Hindu. Panca berarti lima, sapta berarti tujuh. Panca Rsi berarti golongan yang terdiri dari lima sosok rsi, begitu pula dengan Sapta Rsi. Namun rsi yang dimaksud pada pembahasan ini bukan mengacu pada suatu kelompok orang, melainkan entitas ilahi. Panca Rsi dan Sapta Rsi yang dimaksud di sini adalah golongan makhluk ilahi pada tingkatan alam tertentu.

\section{4) Kanda Pat}

Dalam Kamus Kawi-Bali yang disusun Dinas Pendidikan Dasar Provinsi DATI I Bali (1988: pada entri kanda), kanda berarti bagian, sedangkan pat berasal dari kosa kata papat, yang berarti empat. Sehingga, arti dari istilah Kanda Pat adalah empat bagian manusia. Istilah Catur Sanak bahkan memiliki makna personifikasi, yaitu catur berarti empat, dan sanak berarti saudara, Catur Sanak berarti empat saudara gaib manusia. Dalam istilah suluk Jawa atau Kejawen, dikenal dengan istilah Sadulur Patpat Kalimo Pancer yang memiliki arti empat saudara yang kelima sebagai pusatnya, yang maknanya sama dengan Kanda Pat dan $\mathrm{Ca}$ tur Sanak.

\section{5) Dasa Aksara}

Dasa Aksara adalah sepuluh (dasa) aksara suci wijaksara, diantaranya:

Sang $\left(\mathrm{s}^{\mathrm{o}}\right)$, Bang $(\mathrm{b}$,$) , Tang \left(\mathrm{t}^{\mathrm{o}}\right)$, Ang (ö), Ing $(\div)$, Nang $\left(n^{0}\right)$, Mang $(1 / 2)$, Sing $\left({ }^{\prime} \mu\right)$, Wang $\left(\mathrm{w}^{\circ}\right)$, Yang $\left(\mathrm{y}^{\mathrm{o}}\right)$.

Aksara wijaksara adalah suatu aksara inti suci (wija/bija= inti/benih) yang diyakini oleh masyarakat Bali mengandung kesucian, getaran energi magis, bersifat gaib, dan spiritual religius

\section{SIMPULAN}

Kesimpulan dimulai dari struktur teks. Struktur teks yang dimaksud adalah menguraikan teks Tutur Anggastya Prana yang berdasar pada ranah pengamatan dan elemen wacana Van Dijk sekaligus melakukan pendekatan intrinsik karya sastra. Struktur teks tersebut adalah:

1) Struktur Makro: ranah pengamatan struktur ini adalah tematik atau tema. Dalam teks Tutur Anggastya Prana ditemukan tiga tema sekaligus, yaitu (1) tema ketuhanan (divine) dan (2) tema jasmaniah (physical), dan (3) tema sosial. Namun tema pokok/tema mayor dari karya sastra ini adalah tema ketuhanan (divinity).

2) Superstruktur: ranah pengamatan struktur ini adalah skematik atau skema, yang terdiri dari: (1) kalimat pembukaan teks, (2) isi teks, (3) penutup, dan (4) 
skema person.

3) Struktur Mikro: ranah pengamatan struktur ini terdiri dari (1) semantik, (2) sintaksis, (3) stilistika, dan (4) retoris. Namun, ranah semantik diulas pada bab VII pada kajian tentang makna. Ranah sintaksis dipecah lagi menjadi kohesi gramatikal yang menguraikan struktur ketatabahasaan, dan kohesi leksikal yang mengamati keserasian hubungan leksikal pada teks sebagai sebuah wacana. Ranah stilistika mengamati gaya bahasa yang digunakan. Sedangkan ranah retoris mengamati penggunaan majas yang terdapat dalam teks Tutur Anggastya Prana.

\section{UCAPAN TERIMA KASIH}

Penulis mengucapkan terima kasih kepada mitra bestari atas kritikan dan masukan yang membangun untuk perbaikan artikel ini.

\section{DAFTAR PUSTAKA}

Agastia. 1994. Kesusastraan Hindu Indonesia: Sebuah Pengantar. Denpasar: Yayasan Dharma Sastra.

Anom, Ketut dkk. 2008. Kamus Bali-Indonesia: Beraksara Latin dan Bali. Denpasar: Kerjasama Dinas Kebudayaan Kota Denpasar dengan Badan Pembina Bahasa, Akasara, dan Sastra Bali Provinsi Bali.

Arifin. 2012. Modul Teori dan Aplikasi Analisis Wacana. Program Studi Pendidikan Bahasa, Program Pascasarjana UNDIKSHA.

Arwati, Sri Ni Made. 2002. Mansa Yadnya; Upacara Bayi Lahir Sampai Ngotonin. Bali: Pemerintah Provinsi Bali.

Asa Berger, Arthur. 2010. Pengantar Semiotika: Tanda-Tanda Dalam Kebudayaan Kontemporer. Yogyakarta: Tiara Wacana.

Bagus, Lorens. 2005. Kamus Filsafat. Jakarta:
PT Gramedia Pustaka Utama.

Bangli, I.B Putu. 2006. Bhegawan Anggastya Prana. Surabaya: Paramita Surabaya.

Chaer, Abdul. 2011. Tata Bahasa Praktis Bahasa Indonesia. Jakarta: Rineka Cipta.

Danesi, Marcel. 2011. Pesan, Tanda, dan Makna. Diterjemahkan oleh: Evi Setyarini dan Lusi Lian Piantari. Yogyakarta: Jalasutra.

Dwijayanthi. 2013. Wacana Kalepasan Dalam Kakawin Panca Dharma. Universitas Udayana.

Eman, Mayun dkk. 2009. Pedoman Pasang Aksara Bali. Denpasar: Badan Perpustakaan Arsip dan Dokumentasi Kota Denpasar.

Gamabali, Budi. 2015. Ajaran Kanda Pat Bhuta. http://cakepane.blogspot.co.id /2015/07/ ajaran-kanda-pat-bhuta.html

Gamabali, Budi. 2014. Tutur Angastiaprana. http://cakepane.blogspot.co.id /2014/10/ tutur-angastiaprana.html

Geeraerts, Dirk. 2010. Theories of Lexical Semantics. New York: Oxford University Press Inc.

Hovav, Malka R, dkk. 2010. Lexical Semantics, Syntax, and Event Structure. New York: Oxford University Press Inc.

Lugra, I Wayan. 2014. Tutur Begawan Anggastyaprana. https://suaranusapenida. wordpress.com/about/tutur-begawananggastyaprana/

Nala, Ngurah. 2006. A ksara Bali Dalam Usada. Surabaya: Paramita Surabaya.

Nala, Ngurah. 1993. Usada Bali. Denpasar: Upada Sastra.

Nama. 2001. Geguritan Sudamala: Analisis Bentuk, Fungsi dan Makna. Universitas Udayana.

Ninggrat. 2014. Harmonisasi Alam Dalam Teks Kidung Jerum Kundangdya. Universitas Udayana.

Pateda, Mansoer. 2010. Semantik Leksikal. Edisi Kedua. Jakarta: Rineka Cipta.

Pekandelan, Mangku Alit. 2008. Kanda Empat Bhuta: Sakti Seperti Siluman. Surabaya: Paramita Surabaya.

Pekandelan, Mangku Alit. 2007. Kanda Empat Sari: Sakti Tanpa Guru. Surabaya: Paramita Surabaya.

Purwo, Kaswanti B. 1990. PELLBA 3: Pertemuan Linguistik Lembaga Bahasa Atma Jaya: Ketiga. Jakarta: Penerbit Kanisius.

Ratna, Kutha Nyoman. 2010. Metodologi Penelitian: Kajian Budaya dan Ilmu Sosial Pada Umumnya. Yogyakarta: Pustaka Pelajar.

Riana, I Ketut. 2010. Kakawin Gajah Madha: Patih Amangku Bhumi Majapahit. 
Denpasar: PT Percetakan Bali.

Santoso, Anang. Jejak Halliday Dalam Linguistik Kritis dan Analisis Wacana Kritis. Malang: Jurusan Sastra Indonesia, Fak. Sastra Universitas Negeri Malang.

Shashangka, Damar. 2014. Induk Ilmu Kejawen: Wirid Hidayat Jati. Jakarta: Dolphin.

Shashangka, Damar. 2015. Ilmu Jawa Kuno: Sanghyang Tattwajñana Nirmala Nawaruci. Jakarta: Dolphin.

Sobur, Alex. 2009. Analisis Teks Media. Bandung: PT.Remaja Rosdakarya.

Suastika. 1995. Calon Arang Dalam Tradisi Bali: Suntingan Teks, Terjemahan dan Analisis Proses Pem-bali-an. Universitas Gadjah Mada.

Sulistyorini, Dwi. 2015. Filologi: Teori dan Penerapannya. Malang: Madani.
Swastika, Pasek I Ketut.2012. Dharma Kahuripan. Denpasar: Pustaka Bali Post.

Van Dijk, Teun. 2009. Society and Discourse; How Social Contexts Influence Text and Talk. Cambridge University Press.

Warna, Ketut dkk. 1988 Kamus Kawi-Bali. Dinas Pendidikan Dasar Provinsi DATI I Bali.

Wellek, René, Austin Warren. 2014. Teori Kesusastraan. Diterjemahkan oleh: Melani Budiarta. Jakarta: PT Gramedia Pustaka Utama.

Wiatmi. 2013. Sosiologi Sastra; Teori dan Kajian Terhadap Sastra Indonesia. Kanwa Publisher.

Zoetmulder, P.J. 2000. Manunggaling Kawula Gusti: Pantheïsme dan Monoisme Dalam Sastra Suluk Jawa. Jakarta: PT Gramedia Pustaka Utama. 